\title{
Occupational Brucellosis in County Cork
}

\author{
BRIDGET V. FOLEY and JOHN P. CORRIDAN \\ From the Regional Laboratory Service, Cork Health Authority, and the Department of Social Medicine. \\ University College, Cork
}

Three occupational groups exposed to brucellosis hazard were investigated in Cork in 1967, using three standard tests. Of 80 veterinarians, $92.5 \%$ had serological evidence of past or present Brucella infection. If a complement-fixation test of $\mathrm{I} / \mathrm{I} 6$ is accepted as evidence of active disease, $72.5 \%$ of veterinarians, $7.8 \%$ of I02 dairy farmers, and $2 \%$ of 50 butchers in this area have active disease. We feel that brucellosis, while undoubtedly of high infectivity, is more pathogenic than is commonly held. A controlled clinical trial is necessary to elucidate the morbidity of this organism.

As Cork is the centre of the Irish dairy industry, it was decided to investigate the prevalence of brucellosis among certain occupationally exposed groups in the area. Accordingly, veterinarians, dairy farmers, victuallers, and slaughtermen were investigated during the summer of 1967.

\section{Material and Methods}

Three occupational groups were investigated:

(I) Eighty veterinarians in the area completed the questionnaire originally used by Kerr, Coghlan, Payne, and Robertson (1966b). Serum samples were taken from the veterinarians when attending local veterinary conferences with the exception of Nos. 4 and 7 (Table V) who were referred, because of symptoms, by their family doctors.

(2) One hundred and two dairy farmers were randomly selected at cattle markets in Bandon, Mallow, Fermoy, and Kanturk but were not required to complete the questionnaire. Information was, however, elicited regarding the presence or absence of 'contagious abortion' in their herds within the previous five years.

(3) In view of the fact that they handled animal carcasses, serum was also taken from 50 victuallers and slaughtermen in Cork City.

The following three tests were carried out on each specimen of serum:

(I) Standard Brucella agglutination test (S.A.T.) using an antigen prepared by the Veterinary Research Laboratory, Thorndale, Dublin and the method advocated by Cruickshank (I965) with incubation at $37^{\circ} \mathrm{C}$. for 24 hours: This antigen is standardized to the F.A.O./W.H.O. antigen and gives a constantly lower agglutination titre than the usually enployed commercial antigens.

Received for publication December 18, 1967.
(2) Coombs' anti-human globulin test (A.H.G.): Serum, $0.2 \mathrm{ml}$., $+0.8 \mathrm{ml}$. of $0.5 \%$ phenol saline was put up in $2 \times \frac{3}{8}$ test tubes, and $0.5 \mathrm{ml}$. of diluted antigen was added to each tube to give final dilutions of $1 / 10$ to I/5120. The tubes were incubated overnight at $37^{\circ} \mathrm{C}$. They were then read off for clearing of antigen, the last tube with complete clearing being the final titre.

Next, the tubes were spun at 3,000 r.p.m. for 30 minutes. The supernatant was decanted and the antigen button was resuspended in $\mathrm{I} \mathrm{ml}$. of phenol saline. The centrifugation and decanting were again repeated. It was again recentrifuged and decanted and $\mathrm{I} \mathrm{ml}$. of Coombs' anti-human globulin serum (Burroughs Wellcome) diluted I/I60 with sterile normal saline was added to all tubes. They were resuspended and incubated for a further 24 hours at $37^{\circ} \mathrm{C}$. They were then read as in the agglutination test for the clearing of antigen as described by Wilson and Merrifield (I95I).

(3) Complement-fixation test (C.F.T.): Each serum was diluted $50 / 50$ in veronal buffer solution (V.B.S. Oxoid Code No. BRI6) and inactivated for one hour at $56^{\circ} \mathrm{C}$. The antigen was supplied by the Veterinary Research Laboratory, Thorndale, Dublin and was standardized to the F.A.O./W.H.O. International Serum, the working dilution being one which gave a $50 \%$ haemolysis with the International Serum (antigen $1 / 6$ in this series). The haemolytic system and complement were supplied by Burroughs Wellcome. The final dilutions ranged from $I / 4$ to $I /$ IO24.

\section{Results}

The findings of the three tests on the veterinarians, dairy farmers, and butchers are presented in Tables I and II. It will be seen that of the 80 veterinarians, six were negative to all three tests and 37 were positive to all three tests. Of the ro2 dairy farmers, 55 were negative to all three tests and five 
TABLE I

Serum Agglutination and A.H.G. Tests for Br. abortus in Veterinarians, Dairy Farmers, and Butchers

\begin{tabular}{|c|c|c|c|c|c|c|c|c|c|c|c|c|}
\hline & \multirow{2}{*}{$\begin{array}{l}\text { No. of } \\
\text { Sera }\end{array}$} & \multicolumn{9}{|c|}{ Titres } & \multicolumn{2}{|c|}{$\begin{array}{c}\text { Total } \\
\text { Positive }\end{array}$} \\
\hline & & $1 / 10$ & $I / 20$ & $I / 40$ & $I / 80$ & $I / I 60$ & $I / 320$ & $I / 640$ & $I / 1280$ & $r / 2560$ & No. & $\%$ \\
\hline $\begin{array}{l}\text { Veterinarians } \\
\text { S.A.T. } \\
\text { A.H.G. }\end{array}$ & $\begin{array}{l}80 \\
80\end{array}$ & 15 & $\begin{array}{r}10 \\
3\end{array}$ & $\begin{array}{l}6 \\
2\end{array}$ & $\begin{array}{l}5 \\
8\end{array}$ & $\begin{array}{c}2 \\
15\end{array}$ & $\overline{19}$ & $\begin{array}{r}I \\
16\end{array}$ & $\overline{8}$ & - & $\begin{array}{l}39 \\
74\end{array}$ & $\begin{array}{l}48 \cdot 8 \\
92 \cdot 5\end{array}$ \\
\hline $\begin{array}{l}\text { Farmers } \\
\text { S.A.T. } \\
\text { A.H.G. }\end{array}$ & $\begin{array}{l}102 \\
102\end{array}$ & $\begin{array}{r}6 \\
16\end{array}$ & $\begin{array}{r}2 \\
12\end{array}$ & $\overline{6}$ & $\overline{7}$ & $\begin{array}{l}\mathbf{I} \\
\mathbf{I}\end{array}$ & - & - & - & - & $\begin{array}{r}9 \\
45\end{array}$ & $\begin{array}{r}8 \cdot 8 \\
44 \cdot 1\end{array}$ \\
\hline $\begin{array}{l}\text { Butchers } \\
\text { S.A.T. } \\
\text { A.H.G. }\end{array}$ & $\begin{array}{l}50 \\
50\end{array}$ & $\overline{6}$ & - & $\overline{2}$ & $\overline{\mathbf{I}}$ & - & - & - & - & - & $\overline{9}$ & $18 \cdot 0$ \\
\hline
\end{tabular}

TABLE II

C.F.T. FOR BR. ABORTUS IN Veterinarians, DaIRY FARMERS, AND BUTCHERS

\begin{tabular}{|c|c|c|c|c|c|c|c|c|c|c|}
\hline & \multirow{2}{*}{$\begin{array}{l}\text { No. of } \\
\text { Sera }\end{array}$} & \multicolumn{7}{|c|}{ Complement Fixation Titres } & \multicolumn{2}{|c|}{ Total Positive } \\
\hline & & $I / 4$ & $I / 8$ & $I / 16$ & $1 / 32$ & $I / 64$ & $I / 128$ & $I / 256$ & No. & $\%$ \\
\hline $\begin{array}{l}\text { Veterinarians } \\
\text { Farmers } \\
\text { Butchers }\end{array}$ & $\begin{array}{r}80 \\
102 \\
50\end{array}$ & $\begin{array}{l}4 \\
I \\
-\end{array}$ & $\begin{array}{l}8 \\
5 \\
-\end{array}$ & $\begin{array}{r}18 \\
4 \\
1\end{array}$ & $\begin{array}{r}19 \\
4 \\
-\end{array}$ & $\frac{12}{-}$ & $\frac{5}{-}$ & $\frac{4}{-}$ & $\begin{array}{r}70 \\
14 \\
1\end{array}$ & $\begin{array}{r}87 \cdot 5 \\
13 \cdot 7 \\
2 \cdot 0\end{array}$ \\
\hline
\end{tabular}

were positive to all three tests. There were 50 butchers, of whom $4 \mathrm{I}$ were negative to all three tests and none was positive to all three tests.

Veterinarians (Group I) Fifty-five of the 80 veterinarians devoted $75 \%$ or more of their time to cattle work, Io devoted $50 \%$ or more of their time, and two less than $25 \%$. Thirteen were in administrative posts (Table III). Thus $80 \%$ of this group devoted $50 \%$ or more of their time to cattle work.

Of the six veterinarians whose sera were negative to all three tests, only two are full-time practising veterinarians devoting $75 \%$ or more of their attention to cattle work. Two of the remaining four have been in purely administrative posts for many years, one has only recently qualified, and the other, a woman practitioner, occasionally helps in her husband's practice.

Eighteen veterinarians gave a history of previous clinically and serologically diagnosed Brucella infection. Eight $(44.4 \%)$ had a negative S.A.T. All had positive A.H.G. tests, only four giving a reading of less than $I / I 60$, and all had a positive C.F.T. (Table IV). All had worked with SI91
TABLE III

Three Standard Tests in Veterinarians in Administrative Posts

\begin{tabular}{c|l|l|l|c}
\hline $\begin{array}{c}\text { Survey } \\
\text { No. }\end{array}$ & S.A.T. & A.H.G. & C.F.T. & $\begin{array}{c}\text { In } \\
\text { Administration } \\
(y r s)\end{array}$ \\
\hline 9 & 0 & $1 / 20$ & 0 & 25 \\
20 & 0 & $1 / 80$ & $1 / 16$ & 10 \\
21 & 0 & $1 / 40$ & $1 / 4$ & 14 \\
22 & 0 & $1 / 20$ & 0 & 20 \\
32 & $1 / 10$ & $1 / 640$ & $1 / 16$ & 1 \\
34 & 0 & 0 & 0 & 40 \\
53 & 0 & $1 / 80$ & $1 / 8$ & \\
55 & $1 / 10$ & $1 / 160$ & $1 / 32$ & 15 \\
59 & 0 & $1 / 80$ & $1 / 16$ & 6 \\
62 & $1 / 20$ & $1 / 1280$ & $1 / 128$ & 20 \\
65 & 0 & $1 / 40$ & $1 / 4$ & 5 \\
71 & 0 & $1 / 160$ & $1 / 16$ & 7 \\
72 & 0 & 0 & 0 & 30 \\
& & & & 30 \\
\hline
\end{tabular}

1Strain 19 (SI9) is a Brucella organism grown on potato agar medium. It has a greater sensitivity to thionin and penicillin and has a much reduced virulence. It is the antigen of choice to induce powerful and prolonged immunity in calf vaccinations. 
TABLE IV

Serological Findings in Veterinarians With History of Previously Diagnosed Brucellosis

\begin{tabular}{|c|c|c|c|}
\hline Survey No. & S.A.T. & A.H.G. & C.F.T. \\
\hline 19 & 0 & $\mathrm{I} / \mathbf{3 2 0}$ & $1 / 32$ \\
\hline 21 & 0 & $\mathrm{I} / 40$ & $\mathrm{I} / 4$ \\
\hline 23 & $1 / 20$ & $I / 320$ & $1 / 32$ \\
\hline 24 & 0 & $1 / 320$ & $1 / 16$ \\
\hline 29 & I/IO & $1 / 80$ & $r / 16$ \\
\hline 35 & $I / 40$ & $I / 320$ & $I / 64$ \\
\hline 44 & & $1 / 320$ & $1 / 32$ \\
\hline 45 & $\mathrm{I} / 80$ & $\mathbf{I} / \mathbf{1 2 8 0}$ & I $/ 256$ \\
\hline $\begin{array}{l}43 \\
47\end{array}$ & $1 / 640$ & $1 / 2560$ & $\mathrm{I} / 256$ \\
\hline 55 & I / IO & $1 / 160$ & $1 / 32$ \\
\hline 59 & 0 & $1 / 80$ & $1 / 16$ \\
\hline 65 & & $1 / 40$ & $I / 4$ \\
\hline 68 & $I / 40$ & I/1280 & $1 / 64$ \\
\hline 69 & & $1 / 160$ & $1 / 16$ \\
\hline 75 & I/IO & $\mathrm{I} / 640$ & $1 / 64$ \\
\hline 76 & 0 & $1 / 320$ & $I / 64$ \\
\hline 78 & $1 / 20$ & $1 / 1280$ & $1 / 64$ \\
\hline 79 & $\mathrm{I} / 80$ & $1 / 640$ & $\mathrm{I} / 64$ \\
\hline
\end{tabular}

vaccine, and only two had not accidentally injected themselves with this strain.

Thirty-six veterinarians without a history of past clinically suspect Brucella infection had accidentally inoculated themselves with SI9. Two of these 36 had negative readings to all three tests, I8 $(50 \%)$ had a negative S.A.T., 34 had a positive A.H.G., and 33 had a positive C.F.T.

During this investigation, a veterinarian, who had a previously negative history as regards Brucella infection, accidentally inoculated herself with the major contents of an SI9 dose standardized to contain $60,000 \times 10^{6}$ organisms. Her findings are listed in Table V (No. 7).

The remaining group of 26 veterinarians had neither inoculated themselves with SI9 vaccine nor suffered from clinical brucellosis. Four of the six veterinarians negative to all three tests were in this group. Twelve $(46.2 \%)$ had a negative S.A.T., $22(84 \%)$ had a positive A.H.G. (including two of the three veterinarians with an agglutination of I/2560), and $20(76.9 \%)$ had a positive C.F.T. Apart from the four veterinarians with three negative tests, the other two veterinarians who had a negative C.F.T. were one recently qualified and another who has spent the major part of his career in a colonial veterinary service.

The findings of these three groups are compared in Table VI.
TABLE V

Results of Three Standard Tests Before, During, AND AFTER THERAPY IN EIGHT VETERINARIANS (I to 8) AND THREE FARMERS ( 9 to II)

\begin{tabular}{|c|c|c|c|c|}
\hline No. & & S.A.T. & A.H.G. & C.F.T. \\
\hline $\mathbf{r}$ & $\begin{array}{l}\text { Before } \\
\text { During } \\
\text { After }\end{array}$ & $\begin{array}{l}1 / 80 \\
1 / 80 \\
1 / 40\end{array}$ & $\begin{array}{l}1 / 640 \\
I / 320 \\
1 / 640\end{array}$ & $\begin{array}{l}1 / 32 \\
1 / 64 \\
1 / 64\end{array}$ \\
\hline 2 & $\begin{array}{l}\text { Before } \\
\text { During } \\
\text { After }\end{array}$ & $\begin{array}{c}0 \\
0 \\
\text { No } \\
\text { specimen }\end{array}$ & $\begin{array}{c}\text { I/80 } \\
\text { I/160 } \\
\text { No } \\
\text { specimen }\end{array}$ & $\begin{array}{c}\text { I/4 } \\
\text { I/I6 } \\
\text { No } \\
\text { specimen }\end{array}$ \\
\hline 3 & $\begin{array}{l}\text { Before } \\
\text { During } \\
\text { After }\end{array}$ & $\begin{array}{l}0 \\
0 \\
0\end{array}$ & $\begin{array}{l}I / 160 \\
I / 1280 \\
I / 1280\end{array}$ & $\begin{array}{l}I / 64 \\
I / 128 \\
I / 64\end{array}$ \\
\hline 4 & $\begin{array}{l}\text { Before } \\
\text { During } \\
\text { After }\end{array}$ & $\begin{array}{l}1 / 40 \\
1 / 80 \\
1 / 80\end{array}$ & $\begin{array}{l}I / 640 \\
I / 320 \\
I / 640\end{array}$ & $\begin{array}{l}r / 64 \\
r / 64 \\
r / 32\end{array}$ \\
\hline 5 & $\begin{array}{l}\text { Before } \\
\text { During } \\
\text { After }\end{array}$ & $\begin{array}{l}1 / 40 \\
1 / 20 \\
1 / 80\end{array}$ & $\begin{array}{l}I / 1280 \\
1 / 1280 \\
1 / 320\end{array}$ & $\begin{array}{l}I / 64 \\
r / 64 \\
r / 64\end{array}$ \\
\hline 6 & $\begin{array}{l}\text { Before } \\
\text { During } \\
\text { After }\end{array}$ & $\begin{array}{l}\text { O } \\
\text { No } \\
\text { specimen } \\
\text { I/ro }\end{array}$ & $\begin{array}{c}\text { I/320 } \\
\text { No } \\
\text { specimen } \\
\text { I/320 }\end{array}$ & $\begin{array}{c}\text { I/64 } \\
\text { No } \\
\text { specimen } \\
\text { I/64 }\end{array}$ \\
\hline 7 & $\begin{array}{l}\text { After inoculation } \\
\text { ( } 24 \mathrm{hrs)} \\
\text { During therapy } \\
\text { After therapy } \\
\text { (I mth) } \\
\text { After therapy } \\
\text { (6 mths) }\end{array}$ & $\begin{array}{l}I / 160 \\
I / 160 \\
I / 160 \\
I / 80\end{array}$ & $\begin{array}{r}I / I 280 \\
I 1280 \\
I / 1280 \\
I / 640\end{array}$ & $\begin{array}{l}I / 64 \\
I / 64 \\
I / 64 \\
I / 64\end{array}$ \\
\hline 8 & $\begin{array}{l}\text { Before } \\
\text { During } \\
\text { After }\end{array}$ & $\begin{array}{c}\text { I/60 } \\
\text { No } \\
\text { specimen } \\
\text { I/I60 }\end{array}$ & $\begin{array}{c}\text { I/1280 } \\
\text { No } \\
\text { specimen } \\
\text { I/1280 }\end{array}$ & $\begin{array}{c}\text { I/64 } \\
\text { No } \\
\text { specimen } \\
\text { I/128 }\end{array}$ \\
\hline 9 & $\begin{array}{l}\text { Before } \\
\text { During } \\
\text { After }\end{array}$ & $\begin{array}{l}1 / 160 \\
1 / 160 \\
1 / 10\end{array}$ & $\begin{array}{l}1 / 320 \\
1 / 640 \\
1 / 160\end{array}$ & $\begin{array}{l}1 / 32 \\
1 / 64 \\
1 / 16\end{array}$ \\
\hline ro & $\begin{array}{l}\text { Before } \\
\text { During } \\
\text { After }\end{array}$ & $\begin{array}{c}\text { I/Io } \\
\text { No } \\
\text { specimen } \\
\text { o }\end{array}$ & $\begin{array}{c}\text { I/80 } \\
\text { No } \\
\text { specimen } \\
\text { I/I60 }\end{array}$ & $\begin{array}{c}\text { I/16 } \\
\text { No } \\
\text { specimen } \\
\text { I/16 }\end{array}$ \\
\hline II & $\begin{array}{l}\text { Before } \\
\text { During } \\
\text { After }\end{array}$ & $\begin{array}{c}\text { o } \\
\text { No } \\
\text { specimen } \\
0\end{array}$ & $\begin{array}{c}\text { I/320 } \\
\text { No } \\
\text { specimen } \\
\text { I/320 }\end{array}$ & $\begin{array}{c}\text { I/32 } \\
\text { No } \\
\text { specimen } \\
\text { I/32 }\end{array}$ \\
\hline
\end{tabular}

Veterinarian No. 7 accidentally inoculated herself with a large dose of Sig (see text).

Symptomatology At the time of the survey, $58(72.5 \%)$ of the 80 veterinarians examined admitted to symptoms consistent with a Brucella 
TABLE VI

Percentage of Veterinarians Positive to Three Standard Tests

\begin{tabular}{c|c|c|c}
\hline \multirow{2}{*}{ Test } & \multicolumn{3}{|c}{ Veterinarian Groups } \\
\cline { 2 - 4 } & $I$ & 2 & 3 \\
\hline S.A.T. & $56 \%$ & $50 \%$ & $54 \%$ \\
A.H.G. & $100 \%$ & $94 \%$ & $84 \%$ \\
C.F.T. & $100 \%$ & $91 \%$ & $77 \%$ \\
\hline
\end{tabular}

${ }^{1}$ Group I: 18 with previous brucellosis

Group 2: 36 inoculated with SIg but no brucellosis.

Group 3: 26 with no SI9 inoculation or brucellosis.

infection. The commonest complaint was of an erythematous rash aggravated by contact with bovine placenta. This occurred in 39 instances. Next in order of occurrence were low back pain (22), malaise (22), sweating (2I), irritability (20), weakness (I9), rheumatism and arthritis (I8), depression (14), and headache (13).

Eight veterinarians, including the recently accidentally inoculated practitioner, underwent therapy. All felt very much better and their symptoms largely disappeared, but generally their titres rose during therapy (Table V).

Dairy Farmers (Group 2) Of the 55 negative to all three tests, only I2 had a history of contagious abortion in their herds in the past five years. The five positive to all three tests gave the following readings:

\begin{tabular}{c|c|c|c}
\hline No. & S.A.T. & A.H.G. & C.F.T. \\
\hline $\mathrm{I}$ & $\mathrm{I} / 20$ & $\mathrm{I} / 320$ & $\mathrm{I} / \mathrm{16}$ \\
2 & $\mathrm{I} / 160$ & $\mathrm{I} / 320$ & $\mathrm{I} / 32$ \\
3 & $\mathrm{I} / 10$ & $\mathrm{I} / 80$ & $\mathrm{I} / \mathrm{1} 6$ \\
4 & $\mathrm{I} / 10$ & $\mathrm{I} / 80$ & $\mathrm{I} / \mathrm{16}$ \\
5 & I/10 & $\mathrm{I} / 20$ & $\mathrm{I} / 4$ \\
\hline
\end{tabular}

Only No. 5 did not have contagious abortion in his herd. At the time of the survey, No. 2 was actually complaining of severe influenza-type symptoms with pyrexia for several weeks, while No. 4 had a 'P.U.O.' and vague ill health also for several weeks. Both were treated as a Brucella infection (Table V) and reported considerable subjective improvement with a marked increase in well being. The other three did not co-operate in further investigation or treatment.

Twenty-seven farmers with a negative S.A.T. and C.F.T. had a positive A.H.G. Seventeen of these had no history of contagious abortion in their herds. Four farmers had a positive S.A.T. and A.H.G. but a negative C.F.T. and had not had contagious abortion at any time in their herds.

Nine farmers with a negative S.A.T. had a positive A.H.G. and C.F.T. Five of these had a history of herd contagious abortion. One farmer of this group had suspicious symptoms. After therapy he felt extremely well but showed no difference in his titres (Table V, No. II).

Butchers (Group 3) None had a positive S.A.T. Only one had a positive A.H.G. (I/80) and C.F.T. (I/I6). Eight others had a positive A.H.G. These nine were questioned about their possible exposure to infection. The butcher with both readings positive had arthritis, sweating, and low backache and had kept cattle for over 20 years but had never assisted in calving. All nine had, many years ago, either killed recently-aborted cows or 3- to 5-day-old calves. All gave a history of drinking unpasteurized milk on many occasions. Only two of the eight butchers with a positive A.H.G. gave a titre of $r / 40$. The other six had a titre of $r / 20$.

All participating in the survey were informed of their results. The 80 veterinarians and their family doctors were informed of their serological findings. The farmers and butchers with all three tests negative were reassured concerning their freedom from brucellosis. The family doctors of farmers and butchers with positive titres were informed. We recommended therapy in those with a positive A.H.G. and C.F.T. irrespective of the S.A.T. where symptoms were consistent with infection. The following regime was suggested: Streptomycin, I g., and tetracycline, $250 \mathrm{mg}$., six-hourly daily for three weeks, with continuation of the tetracycline for a further four weeks.

Co-operation in therapy was poor, largely, we feel, because of the duration of therapy. Also, although about $75 \%$ of the veterinarians had symptoms, they appear to have accepted a state of vague ill health.

\section{Discussion}

The great difficulty among workers interested in brucellosis is in interpreting the results of the three standard tests, especially in the so-called 'symptomless' case. Reddin, Anderson, Jenness, and Spink (1965) state that a definite diagnosis of acute brucellosis is not difficult to presume in patients with a history and a characteristic course. In our 
series, we presumed that two of the five farmers whom we could follow up, with positive titres to all three tests and suspicious symptoms, could be 'acute' cases. On treatment, they both showed marked improvement, their pyrexia abated, their symptoms disappeared, and they both put on weight. No. 9 showed a rise in A.H.G. and C.F.T. followed by a drop in his three tests. No. ro showed a slight rise in A.H.G., but the C.F.T. was unchanged.

It appears that sustained contact with the Brucella antigen determines the serological findings. The veterinarians, because of the nature of their work, appear to emphasize this point.

Of the 80 veterinarians, $74(92.5 \%)$ had serological evidence of past or present Brucella infection. This compares with the survey by Kerr, Coghlan, Payne, and Robertson (1966a) of 309 veterinarians, $63 \%$ of whom showed serological evidence of infection. The figures for Cork are higher, presumably because $65(80 \%)$ devoted more than $50 \%$ of their time to cattle work. However, these veterinarians cannot with certainty be allocated to 'acute' recrudescence or active chronic categories. Kerr and his colleagues (1966b) say that a C.F.T. titre of $I / 16$ or greater is present in the acute and chronic stages of the disease. If this is so, $58(72.5 \%)$ veterinary surgeons in this survey have active Brucella infection. On the other hand, one veterinary surgeon who has been in an administrative post for the past 14 years and who has a negative S.A.T., an A.H.G. of $I / 40$, and a C.F.T. of $\mathrm{I} / 4$, suffers from periodic influenza-like symptoms and orchitis. There appears to be no hard and fast rule and each case has to be judged on its merits. On the same basis of a C.F.T. of $1 / 16$, six of the veterinarians in administrative posts have active Brucella infections. Similarly, $7 \cdot 8 \%$ of dairy farmers appear to have active infection.

Only one butcher had apparently active chronic infection. It is likely that the positive titres in the butchers originated during the slaughter of recently aborted cows or their calves, though the drinking of raw milk may also be a contributory factor.

Henderson (1967) states that this is a disease of high infectivity and low pathogenicity. Although low pathogenicity may be a feature, there does appear, from the questioning of those with positive serological findings, a picture of vague and unpleasant ill-health. Furthermore, although the numbers accepting therapy were small, the response to therapy was associated with a definite improvement in their general health and well-being.

Kerr and his colleagues (1966a) state that SI9 inoculation is often associated with side-effects. It is of interest to note that, in our series, 22 of the 36 who had inoculation with SI9 had resultant symptoms. Five had conjunctivitis, seven local reactions, sometimes severe, and ro a febrile influenza-like illness, which was incapacitating in some instances.

There is no doubt that brucellosis is an occupational hazard of veterinarians and, to a much lesser though definite extent, of dairy farmers. It does not appear to be a hazard to butchers in this area. A properly controlled clinical trial with therapeutic controls and adequate sera follow-ups over a prolonged period is necessary to elucidate the morbidity caused by this organism.

Our thanks are due to P. J. O'Reilly, M.V.M., M.R.C.V.S., and D. J. O'Reilly, M.S., M.V.B., of the Veterinary Research Laboratory, Thorndale for serological methods and materials, to Messrs. P. Flaherty and M. McCarthy for technical assistance, and to Glaxo Ireland for a supply of disposable syringes.

\section{REFERENCES}

Cruickshank R. (1965). Medical Microbiology, I Ith ed., p. 285. Livingstone, Edinburgh.

Henderson, R. J. (1967). Brucellosis in the dairy-farming community and allied workers of Worcestershire. Lancet, 2, 353-357.

Kerr, W. R., Coghlan, J. D., Payne, D. J. H., and Robertson, L. (1966a). Chronic brucellosis in the practising veterinary surgeon. Vet. Rec., 79, 602-608.

,,--- and - (1966b). The laboratory diagnosis of chronic brucellosis. Lancet, 2, I181-1183.

Reddin, J. L., Anderson, R. K., Jenness, R., and Spink, W. W. (1965). Significance of $7 S$ and macroglobulin Brucella agglutinins in human brucellosis. New Engl. F. Med., 272, 1263-1267.

Wilson, M. M., and Merrifield, E. V. O. (I95I). The antiglobulin (Coombs) test in brucellosis. Lancet, 2, 913-914.

\section{Addendum}

The sera of veterinarians and farmers examined by Dr. L. H. Turner of London showed that $81 \%$ of veterinarians and $74 \%$ of dairy farmers were negative to a variety of leptospirae. 